Teresa Zawojska*

Warszawa

\title{
Wychowanie oparte na wartościach chrześcijańskich jako odpowiedź na poczucie kryzysu sensu we współczesnym świecie
}

Dostrzegalne współcześnie zjawiska utraty poczucia sensu przez młodych i nie tylko młodych ludzi, a także poszukiwania go poza dotychczasowymi ostojami sensu, to jest zasadami moralnymi, obyczajowymi i religijnymi, skłaniają wielu myślicieli do szukania odpowiedzi na pytanie, w jakim kierunku człowiek, odczuwający kryzys sensu, powinien się zwrócić. Odpowiedź na to pytanie jest niezwykle ważna także dla filozofii wychowania, ponieważ jednoznaczne wskazanie, w jakich obszarach rzeczywistości szukać sensu/znaczenia/celu ludzkiego życia, stanowi podstawę teleologii wychowawczej, bez której cały proces wychowania zostałby pozbawiony zasadniczego ukierunkowania. W pedagogice filozoficznej zagadnienie sensu ludzkiego życia, a co za tym idzie, celu wychowania, konkretyzuje się w namyśle nad tym, jaką koncepcję wychowawczą należy realizować, aby wskazywać młodym ludziom obszary, na których znalezienie istotnego sensu życia jest możliwe.

Analizując kwestie sensu - jego utraty lub/i poszukiwania - oraz wychowania ukierunkowanego na poszukiwanie istotnego sensu, nie sposób

* Dr Teresa Zawojska, adiunkt w Szkole Głównej Gospodarstwa Wiejskiego w Warszawie, w Wydziale Nauk Społecznych w Katedrze Edukacji i Kultury. Adres: Wydział Nauk Społecznych SGGW, ul. Nowoursynowska 166,02-787 Warszawa; e-mail: teresa_zawojska@, sggw.pl. 
pominąć kluczowych dla tych zagadnień przemyśleń polskich autorów, takich jak: Władysław Stróżewski, Józef Maria Bocheński, Jerzy Bagrowicz, Mieczysław Albert Krąpiec, Zofia Józefa Zdybicka, Janusz Mariański, Kazimierz Popielski, Stanisław Kowalczyk, Jarosław T. Michalski, Marian Nowak, Barbara Kiereś. To w dużej mierze ich dociekania oraz argumenty, które zawarli w swych książkach, stanowią podstawę do przyjęcia tezy, że chcąc wychowywać człowieka do pełni człowieczeństwa, w tym ukierunkowywać na poszukiwanie sensu swego życia, należy działania wychowawcze ugruntować na wartościach. Stanowisko zbliżone do powyższego głosił także Viktor E. Frankl, którego rozważania filozoficzne na temat sensu życia i praktyczna pomoc w jego poszukiwaniu zagubionemu człowiekowi XX wieku stanowią bezcenną inspirację w tym zakresie. Przy czym większość tych autorów wskazuje na wartości głoszone i realizowane przez religię chrześcijańską.

W niniejszych rozważaniach o kryzysie sensu - o sensie zagubionym, utraconym, nieodnalezionym i sensie poszukiwanym - skupiłam się na następujących kwestiach: Czy odczuwanie kryzysu sensu przez współczesnego człowieka to problem tylko teoretyczny? Na czym polega kryzys i poszukiwanie sensu? Czy człowiek jest kreatorem, czy odkrywcą sensu? Religia chrześcijańska drogą do odkrywania sensu życia? Jaka pedagogia daje rękojmię odnalezienia sensu życia?

\section{Czy odczuwanie kryzysu sensu przez współczesnego czlowieka to problem tylko teoretyczny?}

Od wielu dekad poczucie kryzysu sensu stało się zauważalne w wymiarze globalnym i jednostkowym ${ }^{1}$. Przyczyniły się do niego uwarunkowania zarówno cywilizacyjne, takie jak rozczarowanie dobrobytem niosącym łatwą dostępność dóbr materialnych ${ }^{2}$ przy jednoczesnym deficycie dóbr i wartości duchowych (niematerialnych), jak i ideowe, zwłaszcza dominacja lewicowo-liberalnych ideologii, promujących relatywizm poznawczy i moralny, a także podważanie wszelkiej transcendencji, zwłaszcza Transcendencji w wymiarze religijnym. Widoczne w dzisiejszym świecie coraz szersze kręgi

1 Zob. np. Chantal Delsol, Esej o człowieku późnej nowoczesności, thum. Małgorzata Kowalska (Kraków: Znak, 2003).

${ }^{2}$ Por. np. Piotr Kopiec, Konsumpcjonizm. Perspektywa protestanckiej koncepcji człowieka i społeczeństwa (Lublin: Wydawnictwo KUL, 2016). 
ludzi poddających się poczuciu bezsensu życia to realny dylemat osobowościowy konkretnych osób, a także problem społeczny. Wynikający z kryzysu sensu stan permanentnej ,pustki egzystencjalnej”3 odczuwanej przez wielu ludzi stanowi poważne zagrożenie dla życia jednostkowego i wspólnotowego. Prowadzi do zachwiania równowagi psychicznej i moralnej, przejawiającej się w zagubieniu lub wyobcowaniu społecznym, osamotnieniu wynikającym z braku więzi międzyludzkich ${ }^{4}$. Taki stan prowadzi często do patologii społecznych, przyjmujących coraz nowe formy, zależne od stopnia zaawansowania cywilizacyjnego i ekonomicznego danych społeczności oraz od stopnia wypłukania życia indywidualnego i społecznego z tradycyjnych wartości.

\section{Kryzys i poszukiwanie sensu - to znaczy kryzys i poszukiwanie czego?}

Użyte w tytule słowo „kryzys” jest tu rozumiane zgodnie z wykładnią daną przez Stanisława Kowalczyka: jako załamanie się dotychczasowego stabilnego stanu w jakiejś dziedzinie życia ${ }^{5}$. W przypadku niniejszych rozważań chodzi o załamanie się dotychczasowego poczucia racjonalno-

3 „Das existentielle Vakuum” - termin ten został rozpowszechniony przez Victora E. Frankla - twórcę „teorii sensu” i opartego na tej teorii nowego kierunku w terapii psychologicznejlogoterapii (,Żyjemy obecnie w czasach upadku i zaniku tradycji. [...] Z tego powodu coraz więcej osób zaczyna mieć poczucie pustki i bezsensu, doświadczając - jak ją tu nazywam egzystencjalnej pustki”. Viktor E. Frankl, Wola sensu, Założenia i zastosowanie logoterapii, thum. A. Wolnicka (Warszawa: Wydawnictwo Czarna Owca, 2010), 88-89). W „teorii sensu” poszukuje się odpowiedzi na pytanie, kim może (powinien) stać się człowiek po odnalezieniu sensu życia. W Polsce koncepcja Frankla była analizowana i rozpowszechniana przez Kazimierza Popielskiego (Człowiek - pytanie otwarte. Studia z logoteorii i logoterapii, red. Kazimierz Popielski, Lublin: Redakcja Wydawnictw KUL, 1987), później m.in. przez Arletę Chojniak (Człowiek i sens. Frankla koncepcja autotranscendencji, Poznań: Wydawnictwo Fundacji Humaniora, 2003), Jarosława Michalskiego (Sens życia a pedagogika, Toruń: Wydawnictwo Uniwersytetu Mikołaja Kopernika, 2011).

${ }^{4}$ Frankl przytacza słowa Alberta Einsteina dotyczące destruktywnych dla człowieka skutków poczucia braku sensu życia: „Człowiek, który uważa swe życie za pozbawione sensu, jest nie tylko zwyczajnie nieszczęśliwy, ale i niezdolny do życia”. Frankl, Wola sensu, 71.

${ }_{5}^{5}$ Stanisław Kowalczyk, Współczesny kryzys ideowo-aksjologiczny (Lublin: Wydawnictwo KUL, 2011), 5: „Kryzys jest symptomem załamania się dotychczasowej relatywnie stabilnej sytuacji człowieka czy społeczeństwa, utratą istniejącej równowagi psychicznej, ekonomicznej czy kulturowej". 
ści świata, głównie sensu ludzkiego życia. Pytanie o sens różnych rzeczy i działań - w tym zwłaszcza o sens całości (świata) - stawiane jest zarówno w życiu praktycznym, jaki i w naukach: humanistycznych, społecznych, teologicznych, filozoficznych. W metafizyce klasycznej sens definiuje się jako uporządkowanie, zrozumiałość, racjonalność, wartościowość czegoś (np. zachowania się, życia, dziejów, rzeczywistości) ${ }^{6}$. Pełny sens czegoś daje się poznać w ramach większej struktury (np. część - całość, środki - cel).

Metafizyka klasyczna przyjmuje, że poznawany sens czegoś wynika z bytowego statusu rzeczywistości. To właśnie ontyczna struktura bytu sprawia, że rzeczywistość odznacza się obiektywnym porządkiem, że jest racjonalna. Antropologia klasyczna uszczegóławia, że ludzka potrzeba poszukiwania sensu wynika z ontycznego statusu osoby ludzkiej. Dociekanie sensu staje się przez to problemem uniwersalnym7 ${ }^{7}$ dotyczy każdego człowieka - niezależnie od geograficzno-socjalnych i historycznych uwarunkowań życia, niezależnie od wyznawanej religii (lub areligijności), od przyjętego (lub/i wypracowanego) światopoglądu.

W duchu antropologii klasycznej rozwija swoją ,teorię sensu” także Viktor Frankl, który poszukiwanie sensu uważa za podstawowy przejaw człowieczeństwa. Przyjmuje, że byt ludzki urzeczywistnia się w dążeniu od tego, co jest, do tego, co być powinno ${ }^{8}$.

Zastanawianie się nad sensem rzeczy i działań - w tym nad sensem całości, w przypadku refleksji nad sensem bytu ludzkiego konkretyzuje się w pytaniu o sens/cel/znaczenie życia człowieka. Poszukiwanie sensu życia, to zastanawianie się, w jakim kierunku kształtować swoje życie, w jaki sposób zintegrować różne wydarzenia swego życia, aby tworzyły sensowną całość; na jakich wartościach oprzeć swoje działania. Odpowiedź pada zazwyczaj jednoznaczna: życie danego człowieka ma sens wtedy, gdy dąży on do pewnego celu samosensownego lub podporządkowanego takiemu celowi (Witold Marciszewski, Władysław Stróżewski, Józef Maria Bocheński).

Jak pokazuje ludzkie doświadczenie, pełnię sensu swego życia można odczuwać zarówno w sytuacjach sukcesów, jak i w przypadku klęsk. Podob-

6 Józef Herbut, „Sens”, w: Stownik filozofii klasycznej, red. Józef Herbut (Lublin: Towarzystwo Naukowe KUL, 1997), 476-478.

7 Por. np. Kazimierz Popielski, „«Sens» i «wartość życia» jako kategorie antropologiczno-psychologiczne”, w: Człowiek-pytanie otwarte. Studia z logoteorii i logoterapii, red. Kazimierz Popielski (Lublin: Redakcja Wydawnictw KUL, 1987), 136.

8 ,bycie człowiekiem oznacza istnienie w obliczu sensu, jaki należy wypełnić, i wartości, jakie należy zrealizować. Oznacza życie w biegunowym polu napięć pomiędzy rzeczywistością a ideałami, które mają być zmaterializowane". Frankl, Wola sensu, 73. 
nie jak poczucia braku sensu w życiu można doświadczać zarówno w powodzeniu zewnętrznym, jak i w niepowodzeniu?

\section{Czlowiek kreatorem czy odkrywcą sensu?}

Jeśli zaakceptujemy twierdzenie metafizyki klasycznej, że ontyczną podstawę sensu stanowi racjonalność rzeczywistości, co oznacza, że sens ma podstawę w rzeczy (w rzeczywistości), to musimy przyjąć, że sens nie jest dowolną, subiektywną kreacją człowieka ${ }^{10}$. W metafizyce realistycznej (określanej jako teistyczno-kreacjonistyczna - Józef Herbut ${ }^{11}$ ), dającej filozoficzne podstawy dla teologii chrześcijańskiej, świat ma racjonalną strukturę, i tym samym sens, dzięki pochodności od Absolutu (Boga) ${ }^{12}$. Absolutna bytowość Boska cechuje się absolutną sensownością. W tej sensowności partycypują byty organiczne (przygodne) proporcjonalnie do stopnia doskonałości swego istnienia. Ostatecznie więc istnienie i działanie tych bytów nie ma pełnego sensu w sobie, lecz ma sens dzięki ukierunkowaniu na Byt Absolutny jako byt autosensowny ${ }^{13}$.

${ }^{9}$ Por. Michalski, Sens życia, 133.

${ }_{10}$ Zob. Mieczysław A. Krąpiec, Filozofia co wyjaśnia? Filozofia w teologii (Lublin: Redakcja Wydawnictw KUL, 2000), 150: „Jawi się więc przed ludzkim rozumem racjonalna rzeczywistość (...). Jest to rzeczywistość związana partycypatywnym sposobem istnienia (...). Partycypatywnie - przez Absolut i dzięki Absolutowi - istniejący świat bytów jest rzeczywistością inteligibilną, racjonalną dzięki ostatecznemu związaniu z Absolutem. Absolut stoi u podstaw rzeczywistości jako jej Racja Bytu”. Por. także Mieczysław A. Krąpiec, O rozumienie filozofii (Lublin: Redakcja Wydawnictw KUL, 1991), 191-197.

11 Herbut, „Sens”, 477.

12 „Bóg jako realna absolutna tożsamość jest ostatecznie ontologiczną realną podstawą wszelkiej racjonalnej myśli, opartej w swej strukturze na zasadzie tożsamości. Zasada tożsamości i zasada sprzeczności są nie tylko prawem myśli, lecz i prawem bytu, bo nie jest tak, że w porządku myśli obowiązują inne prawa niż w porządku bytu. Prawa bytu są prawami myśli, bo sama myśl jest refleksem bytu”. Mieczysław A. Krąpiec, Odzyskać świat realny (Lublin: Redakcja Wydawnictw KUL, 1999), 602.

13 „Sieć relacji wewnątrzbytowych i międzybytowych (...) wskazuje na istnienie Absolutu jako ostatecznej racji bytu, a więc Bytu, który oddziela byt od niebytu. Negacja Absolutu w tak rozumianej filozofii nie jest możliwa, albowiem byłoby to równoważne z przekreśleniem wszelkich podstaw racjonalności oraz zgodą na absurd bytu i myśli. Metafizyka uwalnia ludzkie poznanie od absurdu i wskazuje na czynniki uzasadniające racjonalność bytu i myśli”. Mieczysław A. Krąpiec, O rozumienie świata (Lublin: Redakcja Wydawnictw KUL, 2002), 213. 
W wykładni religijnej problem sensu życia znajduje swoje ostateczne wyjaśnienie w Bogu. W tej kwestii warto powołać się na autorytet teologiczny Josepha Ratzingera, który jednoznacznie opowiedział się za obiektywnym pochodzeniem wszelkiego sensu, w tym sensu ludzkiego życia: „Sensu, to znaczy podstawy, na której opiera się cała nasza egzystencja, nie można sobie stworzyć; można go tylko przyjąć"14.

Przeciwne poglądy w kwestii źródeł sensu głoszą np. neokantyści i egzystencjaliści. Zwolennicy neokantyzmu uważają, że byty (realne) są neutralne co do sensu - zyskują go dopiero ze świata wartości. W filozofiach egzystencjalnych byt jako taki nie jest zrozumiały ani sensowny. Sens może mu nadać jedynie człowiek swoimi działaniami i swoją postawą życiową. Przy takich założeniach metafizycznych nieuchronne staje się nihilistyczne przeświadczenie o ostatecznym bezsensie ludzkiej egzystencji i wynikający stąd pesymizm co do ludzkich działań (Jean-Paul Sartre, Martin Heidegger).

Podążając tropem wyznaczonym przez neokantyzm i egzystencjalizm ci, którzy nie szukają lub nie znajdują uzasadnienia sensu życia w racjonalnie pojmowanej rzeczywistości oraz w metafizykalnie uzasadnionej teologii chrześcijańskiej, usiłują znaleźć go w innych obszarach ludzkiej aktywności. Poszukiwanie to jest wówczas ograniczone przyjętym założeniem, że ostatecznym twórcą sensu rzeczy i sensu ludzkiego życia jest człowiek.

\section{Religia chrześcijańska jako droga do odkrywania sensu życia}

Jedno z podstawowych rozróżnień, jakich dokonano analizując ludzkie postawy wobec sensu życia, to wyróżnienie sensu immanentnego (sens horyzontalny, ziemski) oraz sensu transcendentnego (sens wertykalny, absolutny, Boski) ${ }^{15}$. Wielu ludzi, zwłaszcza współcześnie, zabiega wyłącznie o sens immanentny, odrzucając (teoretycznie i/lub praktycznie) możliwość sensu absolutnego. Jednak koleje życia niemal każdego człowieka wymuszają zastanowienie się, czy sens życia i warunkujący go zespół uznawanych wartości wyczerpują się wyłącznie w horyzontalnym wymiarze ludzkiej egzystencji. Z perspektywy socjologicznej można dać odpowiedź twierdzącą,

14 Joseph Ratzinger, Wprowadzenie w chrześcijaństwo, tłum. Zofia Włodkowa (Kraków: Znak, 1971), 35.

15 Por. Janusz Mariański, W poszukiwaniu sensu życia. Szkice socjologiczno-pastoralne (Lublin: Redakcja Wydawnictw KUL, 1990), 67-69. 
gdyż faktem jest, że wielu ludzi usiłuje odnaleźć sens życia wyłącznie w teraźniejszości. Napisano też wiele rozpraw wskazujących, że sensu można (lub należy!) szukać w doczesności ${ }^{16}$. Filozof jest jednak w stanie zweryfikować potoczną opinię, czy człowiek rzeczywiście zadowala się tylko takim rodzajem sensu i czy taki sens jest adekwatny do jego najgłębszych, osobowych oczekiwań? Czy ograniczenie się do upatrywania sensu życia wyłącznie w wymiarze horyzontalnym jest w stanie zaspokoić rzeczywistą ludzką potrzebę posiadania sensu, nadającego kierunek życiu, czy może raczej daje tylko namiastki sensu? Aby zająć stanowisko w tej kwestii, konieczne jest wyeksplikowanie, jak sens życia postrzegany jest w wymiarze wertykalnym, ujawnianym w filozofii realistycznej i w teologii chrześcijańskiej, a jak w wymiarze horyzontalnym, propagowanym w filozofiach tak zwanych humanistycznych (antropocentrycznych).

Jeśli zgodnie z metafizyką realistyczną przyjmiemy, że człowiek nie tworzy racjonalności rzeczywistości, lecz ją odkrywa, to sensu naszego życia będziemy poszukiwać w obiektywnym porządku świata, który jest porządkiem bytów przygodnych, nakierowanych na Byt Absolutny. Zakodowane w naturze człowieka wychodzenie poza siebie w szukaniu wartości ostatecznych znajduje najpełniejsze urzeczywistnienie w wierze w Boga. Bóg gwarantuje życiu i działaniu ludzkiemu pełny (absolutny) sens, gdyż to Bóg wyznacza transcendentną perspektywę życia człowieka, umożliwiającą rozwój pełnego człowieczeństwa. W ten sposób religia chrześcijańska ukazuje się jako wartość antropotwórcza, konstytuująca ludzkie człowieczeństwo. Chrześcijaństwo, dzięki wskazaniu nowej wizji człowieka, ukazało go jako istotę bytującą w perspektywie celu, którym jest życie wieczne. I to ten cel nadaje sens ludzkiemu życiu ${ }^{17}$. Z punktu widzenia antropologii klasycznej (realistycznej) jedynie taki cel-sens jest w stanie satysfakcjonować ludzkie nakierowanie na transcendencję ${ }^{18}$.

Jednak ludzka inklinacja do poszukiwania transcendencji sprawia, że człowiek, korzystając ze swej naturalnej rozumności, szuka namiastek sensu życia - w postaci na przykład samodoskonalenia, samospełnienia, zaanga-

${ }_{16}$ Zob. np. Andre Comte-Sponville, Duchowość ateistyczna. Wprowadzenie do duchowości bez Boga, tłum. Elżbieta Aduszkiewicz (Warszawa: Wydawnictwo Czarna Owca, 2011).

${ }^{17}$ Por. Imelda Chłodna-Błach, Od paidei do kultury wysokiej. Filozoficzno-antropologiczne podstawy sporu o kulturę (Lublin: Wydawnictwo KUL, 2016), 13.

18 „Bez pojawienia się Boga ludzka natura nie mogłaby być racjonalnym układem bytowym, gdyż zasadnicza dążność natury byłaby bezprzedmiotowa, nigdy nie mogąca się spełnić". Krąpiec, O rozumienie filozofii, 296. 
żowania społecznego czy kontemplacji przyrody. Takie poszukiwania zaczęto, przez analogię do tego, co odrzucono, nazywać duchowością. Tymczasem poszukiwanie sensu poza religią - autotranscendencja w wymiarze horyzontalnym (transcendowanie bez Transcendencji) w postaci na przykład poświęcenia się ludziom czy jakiejś wielkiej idei - jest ograniczone do perspektywy ziemskiej. Poszukiwanie sensu wyłącznie w wartościach humanistycznych (ludzkich) wynika z przypisywania im funkcji wartości ostatecznych. Proces ten określa się jako absolutyzowanie wartości relatywnych. Ponadto z praktycznego punktu widzenia zanegowanie wiary w Boga oznacza rezygnację z poczucia bezpieczeństwa, jakie daje religia w kwestii usensownienia ludzkiego życia. Kierunek i cel życia człowieka zostaje pozostawiony do indywidualnej decyzji.

Praktyka życiowa pokazuje, że każda wizja rzeczywistości - poza chrześcijańską - może zostać zachwiana (i najczęściej tak bywa) przez doznane nieszczęście, śmierć osoby bliskiej, a także przez świadomość nieuchronności własnej śmierci. Tąpnięcie światopoglądowe u danej osoby następuje najczęściej wtedy, gdy śmierć jest postrzegana (zgodnie z pozytywistycznym agnostycyzmem) jako zjawisko wyłącznie biologiczne. Śmierć oznacza wówczas unicestwienie dotychczas zakładanego immanentnego sensu życia lub potwierdzenie przeświadczenia o braku jakiegokolwiek sensu, zarówno immentnego, jak i transcendentnego ${ }^{19}$. W perspektywie czysto humanistycznej (laickiej), ukierunkowującej cały system wartości na świat doczesny, śmierć unicestwia wszystkie cele ${ }^{20}$, do których człowiek dążył, a zjawisko śmierci pozostaje zagadnieniem nierozwiązywalnym. Osoby realizujące w swoim życiu tylko cele immanentne kwestionują również poczucie sensu życia. Tę kwestię - niezwykle trudną do wyjaśnienia z punktu widzenia naturalnego rozumu - podejmuje metafizyka klasyczna. Nestor polskiej szkoły filozofii klasycznej, Mieczysław Albert Krąpiec, napisał:

Wydaje się, że stosując metodę filozofii klasycznej, odwołującej się do wyjaśnień czyniących niesprzecznymi dane nam fakty - możemy też do pewnego

19 „Idea całkowitej naturalności ludzkiej śmierci, która nie nasuwa żadnych pytań o sens, wydaje się stanowić istotny składnik nihilizmu obecny we współczesnej kulturze". Vittorio Possenti, „Społeczna marginalizacja śmierci i zmiana jej rozumienia”, w: Vittorio Possenti, Filozofia po nihilizmie (Lublin: Polskie Towarzystwo Tomasza z Akwinu, 2003), 40-41.

20 Janusz Mariański (W poszukiwaniu, 74) wskazuje na konieczność odróżnienia sensu życia (jako całości) od celów życiowych (wielu, różnorakich). Śmierć unicestwia cele, do których dążyliśmy, nie niweluje natomiast sensu życia (jako całości), jeśli sens ten wiązaliśmy z Absolutem. 
stopnia „uniesprzecznić” fakt ludzkiej śmierci. Uniknięcie zaś w tym miejscu absurdu jest już samo w sobie czymś niezmiernie doniosłym. (...). Owo uczynienie niesprzecznym polega $\mathrm{w}$ metafizyce na wskazaniu takiego jedynego czynnika, dzięki któremu dany fakt raczej jest niż nie jest. Czynniki te, w bycie przygodnym zwane przyczynami, sprowadzają się do „sprawcy”, do „,celu”, do „formy” i do „,formy-wzoru” oraz do ,przedmiotu-materii”. Jest to wyliczenie tzw. czterech przyczyn, thumaczących faktyczne istnienie bytu przygodnego ${ }^{21}$.

Dla osób, które sens życia wiążą z Bogiem, śmierć jest tylko zmianą formy życia. Życie i śmierć tworzą nierozdzielną całość, ukazującą sens ostateczny, absolutny. Religijnie pojmowany sens nadaje ludzkiemu życiu wymiar transcendentny, niosąc nadzieję na spełnienie najgłębszych oczekiwań człowieka ${ }^{22}$. To ukierunkowanie poza siebie, transcendowanie siebie, jest charakterystyczną cechą ludzkiego bytowania ${ }^{23}$.

Autor monografii poświęconej immanentnej i transcendentnej wykładni sensu życia - Janusz Mariański - konstatuje, że spośród funkcjonujących filozofii życia to właśnie religia daje najpoważniejsze uzasadnienie sensu, wskazując na jego wymiar transcendentny: ludzkie doświadczenia życiowe wyjaśnia nie przez inne doświadczenia, lecz przez odwołanie się do rzeczywistości ponadempirycznej. Zauważa, że człowiek pozbawiony odniesień do Absolutu wydaje się niepełny, pozbawiony głębszego wymiaru duchowego.

Dzieje ludzkości potwierdzają, że wiele społeczności realizuje sens życia poszerzony o wymiar wertykalny. Przy czym wielu myślicieli, nawet reprezentujących stanowisko teistyczne, nie stawia radykalnej tezy, że obiektywny sens własnego losu i świata można znaleźć jedynie w przyjęciu

${ }^{21}$ Krąpiec, O rozumienie filozofii, 290.

22 „Jeśli nasze poznanie dotyczy bytu, to każdy akt poznania, który nie kończy się intuicją Bytu Absolutnego, jest niedokończony, jest nadal «sproblematyzowany» i nie koi ostatecznie głodu poznawczego. Człowiek ukazałby się jakimś tworem nienaturalnym, bez-sensownym, bo nurtują go ciągle, na mocy natury, pytania egzystencjalne, dotyczące sensu jego własnego istnienia i istnienia całego świata, a odpowiedzi w przeważającej ilości wypadków by nie uzyskiwał (...). Cały bieg natury ludzkiej jako ludzkiej, a więc w momentach poznawczych, będących dążeniem do odkrycia sensu istnienia, dążeniem uwikłanym obiektywnie w każdym akcie poznania intelektualnego, byłby dążeniem bezcelowym, nigdy nie spełnionym. Człowiek nie miałby praktycznie realnej możliwości bezbłędnego i niepowątpiewalnego rozwiązania swych egzystencjalnych pytań”. Krąpiec, O rozumienie filozofii, 293-294.

${ }^{23}$ Frankl nazywa tę właściwość człowieka samotranscendencją („Samotranscendencja stanowi istotę egzystencji. Być człowiekiem, to znaczy być skierowanym na coś innego poza sobą". Frankl, Wola sensu, 71). 
optyki religijnej ${ }^{24}$. Takie stanowisko badaczy wynika zapewne z obawy, że jeśli sens zostanie powiązany wyłącznie z postawą religijną, to jego dostępność zostanie ograniczona do osób wierzących. Jednak z punktu widzenia metafizyki realistycznej (i oczywiście z punktu widzenia teologii chrześcijańskiej) sensy horyzontalne domagają się dopełnienia przez sens wertykalny, gdyż jedynie on przynosi pełny wymiar sensu ${ }^{25}$. Przy czym przyjęcie transcendentnego sensu życia nie oznacza oderwania się od rzeczywistości empirycznej, lecz postrzeganie jej w głębszej perspektywie ${ }^{26}$.

\section{Jaka pedagogia daje rękojmię odnalezienia sensu życia?}

Dla tego, kto jest świadom, że uznanie określonego sensu ludzkiego życia (satysfakcjonującego lub nie) jest uwarunkowane przyjętą wcześniej wizją człowieka (zdefiniowaniem jego statusu bytowego), powyższy dylemat nie nastręcza trudności. W odczytaniu istotnego sensu życia może nieść pomoc tylko taka pedagogia, która została sformułowana na metafizyce ukazującej człowieka jako byt cielesno-duchowy. Taką wizję człowieka przedstawia antropologia klasyczna ${ }^{27}$. Realistyczny obraz człowieka, wydedukowany z analizy ludzkiego działania, wskazuje, że spośród potrzeb duchowych człowieka na czoło wysuwają się potrzeba ładu moralnego (w sobie i wokół siebie) oraz potrzeba poczucia bezspornego sensu własnego życia ${ }^{28}$. Potrzebę sensu działań ludzkich zaspokaja transcendentny cel życia ludzkiego. Na takiej antropologii oparta jest pedagogia chrześcijańska ${ }^{29}, \mathrm{z}$ jej współczesną formą - pedagogiką personalistyczną ${ }^{30}$.

${ }^{24}$ Zwłaszcza Frankl, ale też w niektórych sformułowaniach Mariański.

25 „Cały sens tzw. doczesnego życia ludzkiego wtedy tylko zyskuje wartość, gdy to wszystko, co człowiek czyni teraz, jest tylko zapoczątkowaniem pełni i spełnienia się ludzkiej osoby w jej aktach osobowych". Krąpiec, O rozumienie filozofii, 300.

26 Por. tamże, 57.

${ }^{27}$ Mieczysław A. Krąpiec, Ja-człowiek. Zarys antropologii filozoficznej (Lublin: Towarzystwo Naukowe KUL, 1979).

${ }^{28}$ Por. Robert T. Ptaszek, „Dlaczego nowa duchowość nie może być realną alternatywą dla tradycyjnej religii?", Paedagogia Christiana 1/35 (2015): 113-126.

${ }_{29}$ Pogłębione metodologiczne rozważania na temat statusu pedagogiki chrześcijańskiej w obrębie całości nauk pedagogicznych przeprowadzili Agnieszka Salamucha i Piotr Magier, „W obronie pedagogiki chrześcijańskiej”, Paedagogia Christiana 1/31 (2013): 155-169.

${ }^{30}$ Por. Wolfgang Brezinka, Wychowanie i pedagogika $w$ dobie przemian kulturowych, thum. Jerzy Kochanowicz (Kraków: Wydawnictwo WAM, 2005). 
Pedagogia oparta na wartościach chrześcijańskich jest wskazaniem takiego modelu wychowania, które staje się autentycznym antidotum na cząstkowe, a często iluzoryczne sensy życia proponowane przez nowe ideologie, wywołujące u człowieka poczucie kryzysu sensu.

W dziejach kultury europejskiej powstało wiele koncepcji alternatywnych do wychowania chrześcijańskiego. Ostatnie wieki pokazały, że większość tych pomysłów pedagogicznych nie przyniosła pozytywnych wyników wychowawczych. Uważa się, że brak oczekiwanych efektów wynika z nieadekwatności tych alternatywnych propozycji do kondycji bytowej człowieka-osoby, a często z tą kondycją sprzecznych. Ta nieadekwatność wynika stąd, że pomija się, a nawet neguje chrześcijańską wizję świata i chrześcijańską wizję człowieka. Praktyka pokazała, że wyeliminowanie z życia człowieka postawy religijnej nie nadało sensu jego życiu ${ }^{31}$.

Psychologowie wskazują, że zdolność do doświadczenia sensu nie jest czymś danym z natury, lecz musi być rozwijana w ramach działań wychowawczych. Sensu życia nikt nikomu nie jest w stanie narzucić. Ostatecznie każdy zostaje sam ze swoim sensem (bezsensem) życia. Można jednak pomagać w jego odnalezieniu, i tu jest pole do działania dla wychowawców. Viktor Frankl sformułował postulat zamiany marksistowskiego hasła „walki o byt” na hasło walki o „sens bytu ludzkiego" i wzajemnej pomocy w znalezieniu tego sensu ${ }^{32}$.

Kreatywne pobudzanie do poszukiwania sensu życia przez wskazywanie coraz bardziej wartościowych celów i dążeń jest uważane za ważną funkcję instytucji wychowawczych. Wskazuje się, że powinny być to cele ambitne, lecz realne - dostosowane do wieku i możliwości intelektualnych i społecznych wychowanków, ale wywierające pozytywny wpływ na życie innych ludzi. Ponadto realizacja tych celów powinna ich realizatorom przynosić satysfakcję ${ }^{33}$.

Wychowanie oparte na wartościach chrześcijańskich, wskazujące transcendentny sens życia, dzięki odwołaniu się do Absolutu, do autorytetu Boskiego, daje większą szansę na uporządkowanie i usensownienie życia niż propozycje areligijne ${ }^{34}$. Współcześni teologowie podkreślają, że sens życia

31 Por. Ptaszek, „Dlaczego”, 113-126.

32 Viktor E. Frankl, Homo patiens, tłum. Roman Czarnecki, Zdzisław J. Jaroszewski (Warszawa: Instytut Wydawniczy PAX, 1971), 292.

33 Zob. Mariański, W poszukiwaniu, 321-325.

${ }^{34}$ Por. np. Marian Nowak, Podstawy pedagogiki otwartej. Ujęcie dynamiczne w inspiracji chrześcijańskiej (Lublin: Redakcja Wydawnictw KUL, 2000), s. 399: „W wychowaniu 
ukazywany przez chrześcijaństwo jest sensem integralnym, który nie odbiera człowiekowi możliwości realizowania godziwych celów/sensów bezpośrednich, spełnianych w wymiarach biologicznym, emocjonalnym, społecznym, kulturowym i religijnym ludzkiego życia. Dzięki integralnemu pojmowaniu sensu życia w procesie wychowania łączy się wskazywanie sensu absolutnego z godziwymi etycznie celami realizowanymi w życiu codziennym. „Podstawą sensownego i udanego życia jest umiejętność synchronizacji nadprzyrodzonego i naturalnego wymiaru człowieka" ${ }^{35}$. Takiej synchronizacji wszystkich wymiarów człowieka dostarcza chrześcijańska pedagogika personalistyczna, w której wychowawca jest zobowiązany do wskazania wychowankowi nadrzędnego celu/sensu jego życia. Opinię tę głosi wielu filozofów wychowania i pedagogów. Jednoznacznie wyraziła ją między innymi Barbara Kiereś: „fundamentem procesu wychowania człowieka może być tylko personalizm, ponieważ opiera się on na prawdzie o człowieku, i choć stawia mu duże wymagania (pokazuje jak żyć po ludzku), nie ma innej drogi" ${ }^{\prime 3}$.

\section{Wnioski}

U podstaw rozstrzygnięcia dylematu dotyczącego sensu ludzkiego życia w kontekście właściwej metody wychowawczej leży pytanie dotyczący istoty człowieka, to znaczy jego statusu bytowego. To warunkuje odpowiedź na pytanie, jakie działania rzeczywiście aktualizują potencjalności człowieka, sprawiając, że staje się on coraz bardziej człowiekiem (żyje coraz bardziej na ludzką miarę). Odwołanie się do struktury bytowej człowieka daje metafizyczną podstawę (kryterium) do oceny wszystkich faktów dotyczących człowieka, w tym faktu wychowania. Kryterium to pozwala w sposób zasadny odpowiedzieć na pytanie, który wymiar sensu - wertykalny czy horyzontalny - pomaga w aktualizowaniu ludzkiego człowieczeństwa, a który

chrześcijańskim wyróżnia się ponadto «cel ostateczny», który najogólniej można określić jako wychowanie człowieka nie tylko na najdalej nawet pojętą przyszłość, lecz na wieczność. Oczywiście odczytanie tego celu wymaga rozpoznania tej podstawowej celowości, jaką jest zamiar Boga wobec niego".

${ }^{35}$ Mariański, $W$ poszukiwaniu, 69.

${ }^{36}$ Barbara Kiereś, „Wychowawca a wychowanek. Wspomaganie czy kształcenie?”, w: Wychować charakter (Lublin: Fundacja Servire Veritati Instytut Edukacji Narodowej 2005), 93. 
wymiar stanowi dla tego człowieczeństwa cel/sens pośredni, a często wręcz zagrożenie sensu osobowego.

Rzetelny intelektualnie filozof edukacji nie może nie wskazać, że adekwatną do kondycji bytowej człowieka odpowiedź na pytanie o sens może przynieść tylko taka teoria wychowawcza, która została nabudowana na realistycznej antropologii filozoficznej ukazującej człowieka jako osobę i odczytującej naczelne cele wychowawcze z principiów antropologicznych, to znaczy z duchowo-cielesnej natury człowieka, jego przygodności bytowej, a jednocześnie jego przyrodzonej godności i rozumności. Teoria filozoficznopedagogiczna powinna zostać dopełniona chrześcijańskimi zasadami moralnymi, gdyż tylko osadzona na takiej całości daje szansę na to, by poszukujący sensu swego życia współczesny człowiek nie błądził po manowcach, lecz szedł drogą pewną, wskazaną przez refleksję filozoficzną i tradycję objawioną.

\section{Education Based on Christian Values as a Response to the Crisis of the Sense of Meaning in the Modern World (Summary)}

There is an increasing sense of the loss of any meaning, including its most dangerous (from the individual and social point of view) form - the loss of sense of meaning of the individual life. The goal of this article is to indicate the pedagogical concept, practical application of which in the upbringing of young people would prevent certain individual from the loss of the meaning of life and to indicate to others the infallible path towards rediscovery of such a meaning. Such pedagogy is built upon the philosophy of man as a person i.e. the physical - spiritual being. Such a being in its essence is a being asking about the meaning of itself and its proper actions. It is also a being, which ontological structure is not satisfied with temporary (horizontal) meanings and goals but is searching for the meaning transcending its accidental nature. It is searching for the transcendental meaningfulness. Such meaningfulness can be provided only by such a being in which the accidental nature of the human being is anchored i.e. the absolute Being - God. Thanks to the integral concept of the meaning of life in Christianity, the upbringing based on the values embedded in this religion, it does not stop at indicating the absolute meaning of life but it connects it with the ethically just meanings - purposes realized in everyday life.

Keywords: meaning of life; Christian upbringing; pedagogical teleology; philosophical anthropology. 


\section{Wychowanie oparte na wartościach chrześcijańskich} jako odpowiedź na poczucie kryzysu sensu we współczesnym świecie (Streszczenie)

We współczesnym świecie coraz bardziej powszechne staje się poczucie utraty wszelkiego sensu, w tym najgroźniejsze dla życia indywidualnego i społecznego poczucie utraty sensu własnego życia. Celem artykułu jest wskazanie, według jakiej koncepcji pedagogicznej należałoby wychowywać młodych ludzi, aby jednych powstrzymać od utraty żywionego przez nich sensu życia na ludzką miarę, a innym wskazać niezawodną drogę do odnalezienia tego sensu. Taka pedagogika powinna być nabudowana na filozofii człowieka jako bytu osobowego, a więc cielesno-duchowego. Taki byt ze swej istoty jest bytem pytającym o sens siebie i sens swoich działań. Jednocześnie jest bytem, którego struktura ontyczna nie zadowala się sensami-celami doraźnymi (horyzontalnymi), lecz poszukuje sensu przekraczającego jego przygodność bytową. Poszukuje sensu transcendentnego. Taki sens może zapewnić tylko taki byt, w którym została zakotwiczona przygodność bytowa człowieka, czyli Byt absolutny - Bóg. Dzięki integralnemu pojmowaniu sensu życia przez chrześcijaństwo, w wychowaniu opartym na wartościach zakotwiczonych w tej religii nie poprzestaje się na wskazywaniu absolutnego sensu życia, lecz łączy się go $\mathrm{z}$ godziwymi etycznie celami-sensami realizowanymi w życiu codziennym.

Słowa kluczowe: sens życia; wychowanie chrześcijańskie; teleologia wychowawcza; antropologia filozoficzna.

\section{Bibliografia}

Bagrowicz, Jerzy. Edukacja religijna wspótczesnej młodzieży. Źródta i cele. Torun: Uniwersytet Mikołaja Kopernika, 2000.

Bocheński, Józef M. Sens życia. Kraków: Wydawnictwo Philed, 1993.

Brezinka, Wolfgang. Wychowanie i pedagogika $w$ dobie przemian kulturowych. Tłum. Jerzy Kochanowicz. Kraków: Wydawnictwo WAM, 2005.

Bronk, Andrzej. „Od rozumienia religii jako «opium ludu» do tezy o niezbywalnej obecności religii w świecie”. W: Byt i sens. Księga pamiątkowa VII Polskiego Zjazdu Filozoficznego w Szczecinie 2004 roku, red. Renata Ziemińska, Ireneusz Ziemiński, 62-70. Szczecin: Wydawnictwo Naukowe Uniwersytetu Szczecińskiego, 2005. 
Chłodna-Błach, Imelda. Od paidei do kultury wysokiej. Filozoficzno-antropologiczne podstawy sporu o kulture. Lublin: Wydawnictwo KUL, 2016.

Comte-Sponville, Andre. Duchowość ateistyczna. Wprowadzenie do duchowości bez Boga. Tłum. Elżbieta Aduszkiewicz. Warszawa: Wydawnictwo Czarna Owca, 2011.

Delsol, Chantal. Esej o człowieku późnej nowoczesności. Tłum. Małgorzata Kowalska. Kraków: Znak, 2003.

Frankl, Viktor E. Bóg ukryty. W poszukiwaniu ostatecznego sensu. Tłum. Aleksandra Wolnicka. Warszawa: Wydawnictwo Czarna Owca, 2012.

Frankl, Viktor E. Homo patiens, tłum. Roman Czarnecki, Zdzisław J. Jaroszewski. Warszawa: Instytut Wydawniczy PAX, 1971.

Frank1, Viktor E. Nieuświadomiony Bóg. Tłum. Bohdan Chwedeńczuk. Warszawa: Instytut Wydawniczy PAX, 1978.

Frankl, Viktor E. Wola sensu. Założenia i zastosowanie logoterapii. Tłum. Aleksandra Wolnicka. Warszawa: Wydawnictwo Czarna Owca, 2010.

Herbut, Józef. „Sens”. W: Słownik filozofii klasycznej, red. Józef Herbut, 476-478. Lublin: Towarzystwo Naukowe KUL, 1997.

Kiereś, Barbara. „Wychowawca a wychowanek. Wspomaganie czy kształcenie?” W: Wychować charakter, 81-94. Lublin: Fundacja Servire Veritati Instytut Edukacji Narodowej, 2005.

Kiereś, Barbara. Człowiek $i$ wychowanie. Od osoby do osobowości. Lublin: Wydawnictwo KUL, 2017.

Kiereś, Barbara. U podstaw pedagogiki personalistycznej. Filozoficzny kontekst sporu o wychowanie. Lublin: Polskie Towarzystwo Tomasza z Akwinu, 2015.

Kiereś, Henryk. „Spór o edukację - kontekst filozoficzny”. Cywilizacja 7 (2003): 41-47.

Kopiec, Piotr. Konsumpcjonizm. Perspektywa protestanckiej koncepcji człowieka i społeczeństwa. Lublin: Wydawnictwo KUL, 2016.

Kowalczyk, Stanisław. Podstawy światopoglądu chrześcijańskiego. Wrocław: Wydawnictwo Wrocławskiej Księgarni Archidiecezjalnej, 1995.

Kowalczyk, Stanisław. Współczesny kryzys ideowo-aksjologiczny. Lublin: Wydawnictwo KUL, 2011.

Krąpiec, Mieczysław A. Filozofia co wyjaśnia? Filozofia w teologii. Lublin: Redakcja Wydawnictw KUL, 2000.

Krąpiec, Mieczysław A. Ja-człowiek. Zarys antropologii filozoficznej. Lublin: Towarzystwo Naukowe KUL, 1979.

Krąpiec, Mieczysław A. O rozumienie filozofii. Lublin: Redakcja Wydawnictw KUL, 1991. 
Krąpiec, Mieczysław A. O rozumienie świata. Lublin: Redakcja Wydawnictw KUL, 2002.

Krąpiec, Mieczysław A. Odzyskać świat realny. Lublin: Redakcja Wydawnictw KUL, 1999.

Mariański, Janusz. Religia w społeczeństwie ponowoczesnym. Warszawa: Oficyna Naukowa, 2010.

Mariański, Janusz. W poszukiwaniu sensu życia. Szkice socjologiczno-pastoralne. Lublin: Redakcja Wydawnictw KUL, 1990.

Michalski, Jarosław T. Sens życia a pedagogika. Impulsy myśli Viktora E. Frankla. Toruń: Wydawnictwo Uniwersytetu Mikołaja Kopernika, 2011.

Nowak, Marian. Podstawy pedagogiki otwartej. Ujęcie dynamiczne w inspiracji chrześcijańskiej. Lublin: Redakcja Wydawnictw KUL, 2000.

Olbrycht, Katarzyna. „Religia a wspieranie rozwoju człowieka”. W: Religia a sens bycia człowiekiem, red. Zofia J. Zdybicka, 103-112. Lublin: Redakcja Wydawnictw KUL, 1994.

Pawlak, Zdzisław. „Rola religii w wychowaniu człowieka. Aspekt filozoficzno-teologiczny". W: Edukacyjny potencjat religii, red. Jerzy Bagrowicz, Jarosław Horowski, 105-119. Toruń: Wydawnictwo Naukowe Uniwersytetu Mikołaja Kopernika, 2005.

Popielski, Kazimierz. „«Sens» i «wartość życia» jako kategorie antropologiczno-psychologiczne". W: Czlowiek - pytanie otwarte. Studia z logoteorii i logoterapii, red. Kazimierz Popielski, 107-139. Lublin: Redakcja Wydawnictw KUL, 1987.

Popielski, Kazimierz. „«Wymiar ludzki» - znaczące odkrycie współczesnej psychologii”. W: Czlowiek - pytanie otwarte. Studia z logoteorii i logoterapii, red. Kazimierz Popielski, 7-23. Lublin: Redakcja Wydawnictw KUL, 1987.

Possenti, Vittorio. Filozofia po nihilizmie. Lublin: Polskie Towarzystwo Tomasza z Akwinu, 2003.

Ptaszek, Robert T. „Dlaczego nowa duchowość nie może być realną alternatywą dla tradycyjnej religii?". Paedagogia Christiana 1 (2015): 113-126.

Ratzinger, Joseph. Wprowadzenie w chrześcijaństwo. Tłum. Zofia Włodkowa. Kraków: Znak, 1971.

Salamucha, Agnieszka, Piotr Magier. „W obronie pedagogiki chrześcijańskiej”. Paedagogia Christiana 1 (2013): 155-169.

Sochon, Jan. Religia w projekcie postmodernistycznym. Lublin: Polskie Towarzystwo Tomasza z Akwinu, 2012.

Stróżewski, Władysław. Istnienie i sens. Kraków: Znak, 1994. 
Zawojska, Teresa. „Czy «nowa duchowość» w społeczeństwach ponowoczesnych to (jeszcze) religijność czy (już) gnoza? Stanowiska socjologa oraz filozofa". Przeglad Religioznawczy 3 (2015): 187-201.

Zawojska, Teresa. „Personalistyczna koncepcja człowieka podstawą pedagogiae perennis i pedagogiki chrześcijańskiej”. W: Wychowanie a cywilizacja uzależnień i agresji, red. Alina Rynio, Katarzyna Stępień, 13-27. Lublin: Fundacja Lux Veritate, 2014.

Zdybicka, Zofia J. Czlowiek i religia. Lublin: Polskie Towarzystwo Tomasza z Akwinu, 2006. 
